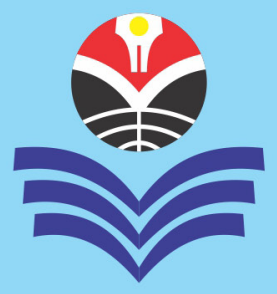

\title{
Kontribusi Hasil Ujian Nasional terhadap Kelulusan Siswa SMP Laboratorium UPI Tahun Pelajaran 2015/2016
}

\begin{abstract}
ABSTRAKSI: UN (Ujian Nasional) tahun 2016 tidak lagi menjadi penentu kelulusan peserta didik dari suatu jenjang pendidikan. Kelulusan peserta didik ditentukan berdasarkan pertimbangan hasil pembelajaran pada seluruh mata pelajaran. Apakah hasil ujian nasional ini berpengaruh terhadap kelulusan peserta didik, khususnya di SMP (Sekolah Menengah Pertama) Laboratorium UPI (Universitas Pendidikan Indonesia) di Bandung? Untuk mengetahuinya dilakukan penelitian atas kontribusi nilai UN terhadap kelulusan siswa. Dengan menggunakan metode penelitian "causal associative" (korelasi), subjek penelitian adalah 134 orang siswa kelas IX SMP Laboratorium UPI. Hasil penelitian menunjukan: (1) Siswa kelas IX SMP Laboratorium UPI tahun pelajaran 2015/2016 secara keseluruhan dinyatakan lulus dengan kategori "sangat baik"; (2) pencapaian nilai hasil UN yang diperoleh siswa kelas IX SMP Laboratorium UPI secara keseluruhan menunjukan kategori "cukup"; serta (3) pencapaian nilai hasil ujian nasional yang diperoleh siswa kelas IX SMP Laboratorium UPI tahun pelajaran 2015/2016 secara keseluruhan memberikan kontribusi positif secara signifikan terhadap tingkat kelulusan siswa yang bersangkutan dengan kontribusi sebesar $69.7 \%$.

KATA KUNCI: Ujian Nasional; Kontribusi; Kelulusan Siswa; Hasil Pembelajaran; SMP Laboratorium.

ABSTRACT: "Contribution of National Examination Results to Students Graduation of UPI Laboratory SMP Lesson Year 2015/2016". UN (National Examination) in 2016 is no longer a determinant of graduation of students from an educational level. Graduation of learners is determined based on consideration of learning outcomes in all subjects. Do the results of this national examination affect the graduation of students, especially in UPI (Indonesia University of Education) Laboratory SMP (Junior High School) in Bandung? To find out it, the research on the contribution of the UN score to the student's graduation. By using research method "causal associative" (correlation), the subject of research is 134 students of class IX UPI Laboratory SMP. The results show that: (1) class IX students of UPI Laboratory SMP in school year 2015/2016 as a whole passed with category is "very good"; (2) the achievement of the score of UN results obtained by grade IX students of UPI Laboratory SMP as a whole shows with "enough" category; and (3) the achievement of score of the national exam results obtained by grade IX students of UPI Laboratory SMP in the academic year 2015/2016 as a whole gives a significant positive contribution to the student's passing rate with a contribution of $69.7 \%$.

KEY WORD: National Examination; Contribution; Graduation of Students; Learning Outcomes; Laboratory Junior High School.
\end{abstract}

About the Author: Dr. Mulyana Abdullah adalah Dosen di Departemen Pendidikan Umum FPIPS UPI (Fakultas Pendidikan Ilmu Pengetahuan Sosial, Universitas Pendidikan Indonesia), Jalan Dr. Setiabudhi No.229 Bandung 40154, Jawa Barat, Indonesia. Alamat e-mail: abdullahmulyana@gmail.com

How to cite this article? Abdullah, Mulyana. (2017). "Kontribusi Hasil Ujian Nasional terhadap Kelulusan Siswa SMP Laboratorium UPI Tahun Pelajaran 2015/2016" in MIMBAR PENDIDIKAN: Jurnal Indonesia untuk Kajian Pendidikan, Vol.2(2), September, pp.163-172. Bandung, Indonesia: UPI [Indonesia University of Education] Press, ISSN 2527-3868 (print) and 2503-457X (online).

Chronicle of the article: Accepted (June 1, 2017); Revised (July 30, 2017); and Published (September 30, 2017). 


\section{PENDAHULUAN}

Hasil yang diharapkan dapat dicapai melalui sistem pendidikan nasional, tidak hanya sebatas kemampuan atau kompetensi pengetahuan saja, namun juga mencakup kompetensi sikap religius dan sikap sosial serta keterampilan peserta didik (Muhadjir, 1993; Setneg RI, 2000 dan 2003; dan Putra, Kamil \& Pramudia, 2017). Oleh karenanya, pemerintah telah menetapkan suatu standar kompetensi lulusan yang dituangkan dalam Peraturan Menteri Pendidikan dan Kebudayaan Nomor 54 Tahun 2013 tentang Standar Kompetensi Lulusan (SKL), yang digunakan sebagai acuan utama pengembangan standar isi, standar proses, standar penilaian pendidikan, standar pendidik dan tenaga kependidikan, standar sarana dan prasarana, standar pengelolaan, serta standar pembiayaan dalam pendidikan (Kemendikbud RI, 2013). Standar kompetensi inilah yang menjadi acuan dalam layanan pendidikan pada tiap satuan pendidikan di Indonesia pada tahun pelajaran 2015/2016.

Sehubungan dengan itu, proses penyelenggaraan pendidikan di SMP (Sekolah Menengah Pertama) Laboratorium UPI (Universitas Pendidikan Indonesia) di Bandung diarahkan pada upaya mewujudkan kompetensi peserta didik yang berkualitas dalam hal akademis, sosial, dan religi, sehingga terbentuk karakter pribadi yang kompetitif dan kreatif (Maryani \& Sjamsuddin, 2009). Upaya ini sejalan dengan SKL (Standar Kompetensi Lulusan), dimana di dalamnya memuat tiga dimensi utama, yaitu: dimensi sikap, dimensi pengetahuan, dan dimensi keterampilan (Kemendikbud RI, 2013).

Keseluruhan pencapaian ketiga dimensi kompetensi peserta didik tersebut dituangkan dalam laporan kelulusan peserta didik, yang memuat hasil ujian sekolah dan ujian nasional, serta rata-rata hasil pencapaian kompetensi tiap semester untuk semua mata pelajaran (Charles, Lester \&
Daffer, 1991; Nitko, 1996; dan Binkley et al., 2010). Berkenaan dengan adanya perubahan dalam kebijakan ujian nasional bahwa ujian nasional, sejak tahun 2015, tidak lagi menjadi penentu kelulusan peserta didik dari suatu jenjang pendidikan (Sulistyo, 2007; dan Kemdikbud RI, 2015a). Hal tersebut memunculkan suatu persoalan, apakah hasil ujian nasional ini berpengaruh terhadap kelulusan peserta didik, khususnya di SMP Laboratorium UPI?

Untuk mengetahuinya, dipandang perlu dilakukannya penelitian atas kontribusi nilai UN (Ujian Nasional) terhadap kelulusan siswa ini. Berdasarkan fenomena yang telah diuraikan pada latar belakang, masalah dalam penelitian ini dirumuskan sebagai berikut: (1) Bagaimana kondisi kelulusan siswa kelas IX SMP Laboratorium UPI tahun pelajaran 2015/2016?; (2) Bagaimana perolehan hasil ujian nasional siswa kelas IX SMP Laboratorium UPI tahun pelajaran 2015/2016?; serta (3) Bagaimana kontribusi perolehan hasil ujian nasional terhadap kelulusan siswa kelas IX SMP Laboratorium UPI tahun pelajaran 2015/2016?

\section{Ujian Nasional dalam Perspektif}

Pendidikan. Istilah "ujian" secara terminologi, menurut KBBI (Kamus Besar Bahasa Indonesia), diartikan sebagai sesuatu yang dipakai untuk menguji mutu sesuatu, seperti: kepandaian, kemampuan, hasil belajar, dan sebagainya. ${ }^{1}$ Berkenaan dengan konsep ujian nasional, "ujian" dalam hal ini lebih ditujukan pada suatu proses untuk mengukur kemampuan peserta didik, khususnya di sekolah, setelah mengikuti suatu proses pembelajaran (Mueller, 1992; Forster \& Masters, 1996; dan Sulistyo, 2007). Hal ini juga ditegaskan dalam Peraturan Menteri Pendidikan dan Kebudayaan RI (Republik Indonesia)

'Lihat "Ujian" dalam KBBI (Kamus Besar Bahasa Indonesia). Jakarta: Kementerian Pendidikan dan Kebudayaan Republik Indonesia, 2016. Tersedia secara online juga di: http://www.kbbi.web.id [diakses di Bandung, Indonesia: 12 Oktober 2016]. 
Nomor 5 Tahun 2015, pasal 1 ayat 5, yang menyatakan sebagai berikut:

Ujian Nasional, yang selanjutnya disebut $\mathrm{UN}$, adalah kegiatan pengukuran dan penilaian pencapaian kompetensi lulusan secara nasional pada mata pelajaran tertentu (Kemendikbud RI, 2015b).

Dalam perspektif pendidikan, ujian adalah bagian dari sistem yang dapat mendorong proses pengajaran guru dan pembelajaran siswa. Ujian memiliki fungsi korektif yang berdampak pada kegiatan mengajar guru dan kegiatan belajar siswa (Charles, Lester \& Daffer, 1991; Mueller, 1992; Forster \& Masters, 1996; dan Binkley et al., 2010). Dengan demikian, dapat dikatakan bahwa ujian nasional ini tidak dapat terpisahkan dari kegiatan pembelajaran, sebagaimana dikemukakan oleh J. Athanasou \& I. Lamprianou (2002), sebagai berikut:

Setiap kegiatan pembelajaran dan pengajaran diikuti dan/atau diiringi dengan suatu kegiatan yang tak terpisahkan lainnya, yaitu ujian. Ujian semacam ini dapat dirancang untuk mengukur setidaknya dua hal, yaitu kemajuan hasil belajar siswa dan keefektifan pengajaran (Athanasou \& Lamprianou, 2002:8).

Sebagai alat ukur, ujian nasional perlu memenuhi syarat-syarat tertentu, karena kualitas informasi dari hasilnya akan berpengaruh terhadap tindak lanjut yang diambil (Nitko, 1996:9-13). Syaratsyarat yang dimaksud di antaranya adalah reliabilitas, validitas, dan kepraktisannya yang memadai ( $c f$ Charles, Lester \& Daffer, 1991; Mueller, 1992; Forster \& Masters, 1996; Nitko, 1996; dan Binkley et al., 2010).

\section{Keterkaitan Ujian Nasional dan} Kelulusan Peserta Didik. Ujian nasional yang diterapkan di Indonesia, khususnya pada satuan pendidikan SMP (Sekolah Menengah Pertama), mencakup empat mata pelajaran, yaitu: Bahasa Indonesia,
Matematika, Bahasa Inggeris, dan IPA atau Ilmu Pengetahuan Alam. Keempat mata pelajaran itu menjadi mata uji dalam ujian nasional tingkat SMP pada tahun 2015, dengan soal tes yang distandarisasi secara nasional (BSNP, 2015; dan Kemdikbud RI, 2015).

Dalam setiap ujian yang distandarkan, menurut M. Phillips et al. (1998) dan N. Hidayah (2013), selalu mengasumsikan peserta ujian mengerjakan tes dalam kondisi yang sama; sementara tidak ada yang dapat menjamin para peserta ujian berada dalam kondisi psikologis yang sama pada saat ujian berlangsung, maka muncul persoalan bahwa tes yang distandarkan dapat menimbulkan kecemasan pada diri peserta ujian (Phillips et al., 1998; dan Hidayah, 2013:39). Itulah sebabnya, perubahan dalam sistem ujian nasional, yang sejak tahun 2015 tidak lagi dijadikan sebagai penentu kelulusan peserta didik, cukup beralasan.

Lantas, apa yang menjadi patokan penentu kelulusan peserta didik? Dalam Peraturan Menteri Pendidikan dan Kebudayaan Nomor 57 Tahun 2015, pasal 26 ayat 1 , ditegaskan bahwa kriteria kelulusan peserta didik dari ujian sekolah/ madrasah untuk semua mata pelajaran ditetapkan oleh satuan pendidikan berdasarkan perolehan nilai ujian sekolah/ madrasah (BSNP, 2015; Kemendikbud RI, 2015c; dan Maulipaksi, 2016). Dengan demikian dapat disimpulkan bahwa keberadaan nilai hasil ujian nasional peserta didik, yang mencakup beberapa mata pelajaran tertentu, tidak lagi menjadi penentu kelulusan peserta didik yang bersangkutan, namun sejajar dengan mata pelajaran lain yang tidak di-UN-kan sebagai salah satu bahan pertimbangan kelulusan bagi satuan pendidikan.

Hipotesis. Sesuai dengan masalah dan tujuan penelitian yang telah ditetapkan, serta dilandasi oleh beberapa teori dasar mengenai ujian nasional dan kelulusan peserta didik dalam suatu satuan pendidikan, 
khususnya tingkat SMP dalam penelitian, maka hipotesis penelitian yang diajukan adalah perolehan nilai ujian nasional berkontribusi positif terhadap tingkat kelulusan siswa kelas IX SMP (Sekolah Menengah Pertama) Laboratorium UPI (Universitas Pendidikan Indonesia) di Bandung tahun 2016.

\section{METODE PENELITIAN}

Desain Penelitian. Secara keseluruhan, penggunaan metode dalam penelitian ini adalah metode penelitian assosiatif-kausal (causal associative), atau sering disebut dengan "penelitian korelasi" (Arikunto, 2010; dan Sugiyono, 2012). Metode ini digunakan untuk menemukan ada tidaknya hubungan sebab-akibat; dan apabila ada, berapa eratnya hubungan serta berarti atau tidak hubungan itu.

Dengan mengacu pada masalah yang dirumuskan, serta metode dan pendekatan yang digunakan, penelitian ini didesain sebagai penelitian yang bersifat korelatifasosiatif, yang dimaksudkan untuk mengetahui ada tidaknya kontribusi hasil ujian nasional terhadap kelulusan siswa di SMP (Sekola Menengah Pertama) Laboratorium UPI (Universitas Pendidikan Indonesia) di Bandung.

Subjek dan Objek Penelitian. Sesuai dengan masalah yang telah dirumuskan, penelitian ini mengambil lokasi di SMP (Sekola Menengah Pertama) Laboratorium UPI (Universitas Pendidikan Indonesia) di Bandung, dengan subjek terdiri atas 134 orang siswa kelas IX tahun pelajaran 2015/2016.

Sementara itu, objek penelitian ini difokuskan pada perolehan nilai ujian nasional dan tingkat kelulusan siswa kelas IX SMP Laboratorium UPI tahun 2016.

Teknik Analisis Data. Sesuai dengan pendekatan yang digunakan dalam penelitian ini, sebagai suatu penelitian deskriptif dengan menggunakan pendekatan kuantitatif dalam pengolahan datanya
(Arikunto, 2010; dan Sugiyono, 2012), digunakan teknik analisis korelasi-regresi sederhana untuk mengkaji keterkaitan antara kedua variabel penelitian, yaitu hasil perolehan (nilai) ujian nasional sebagai variabel $\mathrm{X}$ dan tingkat kelulusan siswa sebagai variabel Y.

\section{HASIL PENELITIAN DAN PEMBAHASAN}

Pertama, Tingkat Kelulusan Siswa Kelas IX SMP Laboratorium UPI Tahun Pelajaran 2015/2016. Didalam Permendikbud (Peraturan Menteri Pendidikan dan Kebudayaan) Nomor 57 Tahun 2015, pasal 25 ayat 1, ditegaskan bahwa penyelesaian seluruh program pembelajaran, sebagaimana dimaksud dalam pasal 24 huruf a, untuk peserta didik SMP/MTs (Sekolah Menengah Pertama/ Madrasah Tsanawiyah) dan SMPLB (Sekolah Menengah Pertama Luar Biasa), apabila telah menyelesaikan pembelajaran dari kelas VII sampai dengan kelas IX; serta pada pasal 26 ayat 1 , yang menegaskan bahwa kriteria kelulusan peserta didik dari ujian sekolah/madrasah untuk semua mata pelajaran ditetapkan oleh satuan pendidikan berdasarkan perolehan nilai ujian sekolah/ madrasah (Kemendikbud RI, 2015c; dan Maulipaksi, 2016).

Ini berarti bahwa kelulusan peserta didik dipertimbangkan dari keseluruhan hasil proses pembelajaran yang mencakup kompetensi sikap, pengetahuan, dan keterampilan yang dicapai peserta didik mulai dari semester I hingga semester $\mathrm{V}$, serta pertimbangan terhadap hasil pembelajaran pada semester VI dan hasil ujian nasional/ujian sekolah.

Berdasarkan hasil pertimbangan pihak sekolah terhadap hasil proses pembelajaran siswa kelas IX SMP Laboratorium UPI tahun pelajaran 2015/2016, mulai dari hasil pembelajaran pada semester I hingga semester V serta pertimbangan terhadap hasil pembelajaran pada semester VI, hasil 
Tabel 1:

Persentase Kelulusan Siswa Tahun 2016

\begin{tabular}{cccc}
\hline No. & Pencapaian Kompetensi & Jumlah Siswa & Persentase (\%) \\
\hline 1 & $>85-100$ & 86 & 64.18 \\
2 & $>70-85$ & 48 & 35.82 \\
\hline & Jumlah & $\mathbf{1 3 4}$ & $\mathbf{1 0 0 . 0 0}$ \\
\hline
\end{tabular}

Sumber: "Data Kelulusan Siswa SMP Lab UPI Tahun 2016".

ujian sekolah, dan hasil ujian nasional, maka tingkat kelulusan siswa kelas IX SMP Laboratorium UPI tersebut menunjukan bahwa keseluruhan siswa kelas IX tahun pelajaran 2015/2016 di SMP, yang berjumlah 134 orang, dinyatakan lulus dengan rata-rata pencapaian kompetensi secara keseluruhan sebesar 86.88744 . Dengan demikian dapat dikatakan bahwa rata-rata tingkat kelulusan siswa kelas IX SMP Laboratosium UPI tahun pelajaran 2015/2016 termasuk pada kategori "sangat baik". Lihat tabel 1.

Semengtara itu, dari jumlah individu, pencapaian kompetensi siswa kelas IX SMP (Sekolah Menengah Pertama) Laboratorium UPI (Universitas Pendidikan Indonesia) di Bandung pada kelulusan tahun 2016 menunjukan bahwa sebagian besar (64.18\%) siswa dinyatakan lulus dengan pencapaian kompetensi pada kategori "sangat baik" $(>85-100)$. Sedangkan sisanya (35.82\%) dinyatakan lulus dengan pencapaian kompetensi pada kategori "baik" (> $70-85)$.

Hasil kelulusan tersebut mengindikasikan bahwa proses pembelajaran yang diberikan kepada siswa kelas IX tahun pelajaran 2015/2016 di SMP Laboratorium UPI mampu mendorong keberhasilan belajar siswa yang bersangkutan, sehingga dapat mencapai kompetensi kelulusan yang "sangat baik".

Kedua, Perolehan Hasil Ujian Nasional Siswa Kelas IX SMP Laboratorium UPI Tahun Pelajaran 2015/2016. UN (Ujian Nasional) sebagai suatu kegiatan pengukuran capaian kompetensi lulusan pada mata pelajaran tertentu secara nasional, dengan mengacu pada SKL (Standar Kompetensi Lulusan), merupakan suatu instrumen bagi pemerintah dalam memperoleh masukan untuk menetapkan kebijakan mengenai hal-hal yang perlu dikembangkan dalam sistem pendidikan nasional (Kemendikbud RI, 2013).

Oleh karenanya, mulai tahun 2016, hasil dari proses ujian nasional ini tidak lagi dijadikan sebagai penentu kelulusan siswa, namun lebih dititikberatkan sebagai bahan kajian dan pertimbangan dalam memperbaiki sistem pendidikan, termasuk proses pembelajaran yang diterapkan pada setiap tingkat satuan pendidikan atau sekolah. Ujian memiliki fungsi korektif, yang berdampak pada kegiatan mengajar guru dan kegiatan belajar siswa (Charles, Lester \& Daffer, 1991; Mueller, 1992; Forster \& Masters, 1996; dan Binkley et al., 2010).

Dengan demikian dapat dikatakan bahwa ujian nasional tidak dapat terpisahkan dari kegiatan pembelajaran. Sebagaimana juga dikemukakan J. Athanasou \& I. Lamprianou (2002) bahwa setiap kegiatan pembelajaran dan pengajaran diikuti dan/ atau diiringi dengan suatu kegiatan yang tak terpisahkan lainnya, yaitu ujian (Athanasou \& Lamprianou, 2002:8). Ujian semacam ini dapat dirancang untuk mengukur setidaknya dua hal, yaitu: kemajuan hasil belajar siswa dan keefektifan pengajaran (Bachman, 1990).

Dengan dilandasi oleh dasar pemikiran tersebut, maka sudah selayaknya setiap satuan pendidikan menjadikan capaian hasil ujian nasional siswa ini sebagai bahan pengkajian dan pertimbangan layanan pembelajaran siswa, di samping sebagai 
Tabel 2:

Capaian Hasil UN Siswa Tahun 2016

\begin{tabular}{ccc}
\hline No. & Mata Pelajaran & Rata-rata Capaian \\
\hline 1 & Bahasa Indonesia & 80.84 \\
2 & Bahasa Inggeris & 74.18 \\
3 & Matematika & 53.23 \\
4 & Ilmu Pengetahuan Alam & 60.52 \\
\hline & Rata-rata Keseluruhan & $\mathbf{6 7 . 1 9}$ \\
\hline
\end{tabular}

Sumber: "Data Nilai UN Siswa SMP Lab UPI Tahun 2016".

salah satu indikator keberhasilan pelayanan pembelajaran. Demikian pula halnya dengan SMP Laboratorium UPI, yang tampak dari capaian hasil ujian nasional tahun 2016, maka siswa kelas IX SMP Laboratorium UPI secara umum telah mampu mencapai jumlah sebesar 268.77 dari keempat mata ujian, dengan rata-rata tiap mata pelajaran sebesar 67.19. Sementara itu, rata-rata capaian nilai tertinggi adalah Bahasa Indonesia sebesar 80.84 , dan rata-rata terendah adalah Matematika sebesar 53.23. Lihat tabel 2.

Dari capaian hasil ujian nasional tersebut dapat dikatakan bahwa jika dikaitkan dengan kategori capaian pada Permendikbud (Peraturan Menteri Pendidikan dan Kebudayaan) Nomor 5 Tahun 2015, secara keseluruhan, rata-rata capaian hasil ujian nasional tahun 2016, yang diperoleh siswa kelas IX SMP (Sekolah Menengah Pertama) Laboratorium UPI (Universitas Pendidikan Indonesia) di Bandung berada pada kategori "cukup".

Kondisi ini tentu saja akan menjadi bahan pertimbangan dalam penentuan kelulusan siswa itu sendiri; dan yang terpenting adalah menjadi bahan pertimbangan dalam pengambilan kebijakan pelayanan pembelajaran di SMP Laboratorium UPI untuk tahun pelajaran berikutnya ( $c f$ Sulistyo, 2007; dan Maryani \& Sjamsuddin, 2009).

\section{Ketiga, Kontribusi Perolehan Hasil Ujian Nasional terhadap Kelulusan Siswa Kelas IX SMP Laboratorium}

UPI Tahun Pelajaran 2015/2016. Sesuai dengan tujuannya, ujian dalam suatu proses pembelajaran merupakan achievement orientation, dimana ujian dapat dirancang untuk mengukur setidaknya dua hal, yaitu: kemajuan hasil belajar siswa dan keefektifan proses pembelajaran yang mereka ikuti (Bachman, 1990).

Berkaitan dengan itu, proses ujian nasional yang diterapkan di Indonesia, yang sejak tahun 2016 tidak lagi dijadikan penentu kelulusan siswa, dapat dipastikan bahwa hasil layanan proses pembelajaran di satuan pendidikan tersebut, baik pada mata pelajaran yang menjadi mata ujian nasional maupun mata ujian sekolah, sama-sama memiliki peluang untuk mempengaruhi dan menentukan keberhasilan belajar siswa pada satuan pendidikan yang bersangkutan, dalam istilah lain disebut sebagai "kelulusan" (Maulipaksi, 2016).

Sesuai dengan masalah yang dirumuskan dalam penelitian ini, yakni bagaimana kontribusi perolehan hasil ujian nasional terhadap kelulusan siswa kelas IX SMP (Sekolah Menengah Pertama) Laboratorium UPI (Universitas Pendidikan Indonesia) tahun pelajaran 2015/2016, serta hipotesis yang didasarkan pada beberapa asumsi teoritis, yakni bahwa perolehan nilai ujian nasional berkontribusi positif terhadap tingkat kelulusan siswa kelas IX SMP Laboratorium UPI tahun 2016, maka dalam pemecahan masalah dan pengujian hipotesisnya dilakukan dalam proses analisis penelitian ini. 
Untuk mengetahui dan menentukan teknik statistik apa yang digunakan pada pengolahan data selanjutnya, proses pertama dalam analisis ini adalah pengujian normalitas terhadap data hasil capaian ujian nasional siswa dan tingkat kelulusan siswa kelas IX SMP Laboratorium UPI tahun pelajaran 2015/2016. Proses pengujiannya dilakukan dengan formula indeks normalitas Kolmogorof-Smirnov (dalam Jumiati, Sari \& Akmalia, 2011).

Berdasarkan hasil uji normalitas terhadap data hasil capaian ujian nasional siswa kelas IX SMP Laboratorium UPI sebagai variabel bebas (independent variable) tampak bahwa distribusi data tersebut terbukti "normal", yang ditunjukkan dengan harga indeks Kolmogorof-Smirnof (Z) sebesar 0.898 lebih besar dari nilai kritiknya sebesar 0.395. Sementara itu, hasil uji normalitas terhadap data tingkat kelulusan siswa kelas IX SMP Laboratorium UPI sebagai variabel terikat (dependent variable) tampak bahwa distribusi data tersebut terbukti "normal". Hal ini ditunjukkan dengan harga indeks $\mathrm{Z}$ sebesar 1.018 lebih besar dari nilai kritiknya sebesar 0.251 .

Berdasarkan hasil uji normalitas terhadap data kedua variabel penelitian tadi dapat disimpulkan bahwa distribusi data yang berhasil dikumpulkan dinyatakan "normal", sehingga dapat dilanjutkan terhadap analisis pengujian hipotesis.

Tahap pengujian yang dilakukan untuk membuktikan adanya kontribusi variabel hasil capaian ujian nasional $(\mathrm{X})$ terhadap variabel tingkat kelulusan (Y) siswa kelas IX SMP Laboratorium UPI tahun pelajaran 2015/2016 dalam penelitian ini adalah dengan menerapkan pengujian koefisien korelasi (r) momen hasil kali atau product moment dari Pearson (dalam Arikunto, 2010; Jumiati, Sari \& Akmalia, 2011; dan Sugiyono, 2012).

Hasil yang diperoleh menunjukan bahwa harga koefisien korelasi (r) sebesar 0.835 dan dinyatakan adanya korelasi yang signifikan pada taraf kesalahan 0.01. Adapun besarnya kontribusi hasil capaian ujian nasional siswa terhadap tingkat kelulusan siswa kelas IX SMP Laboratorium UPI tahun pelajaran 2015/2016 ini diketahui dari hasil perhitungan KD (Koefisien Determinasi) yang menunjukan harga sebesar $69.7 \%$.

Tahap selanjutnya adalah melakukan uji persamaan regresi antara variabel hasil capaian ujian nasional (X) dengan variabel tingkat kelulusan (Y) siswa kelas IX SMP Laboratorium UPI tahun pelajaran 2015/2016. Hasil pengujian regresi terhadap data kedua variabel dalam penelitian ini menunjukan adanya persamaan linier (berbanding lurus) yang positif. Dari hasil perhitungan tersebut dapat diketahui persamaan regresi antara kedua variabel, sebagai berikut:

$$
y=73,349+0,50 x
$$

Persamaan tersebut menunjukan bahwa setiap satu satuan peningkatan yang terjadi pada variabel $X$ akan meningkatkan harga variabel Y sebesar 0.5 satuan. Berdasarkan pada hasil proses pengujian hipotesis tersebut, yaitu hasil pengujian korelasi dan regresi sederhana, sebagaimana telah diuraikan tadi, maka dapat disimpulkan bahwa "pencapaian hasil ujian nasional siswa kelas IX SMP Laboratorium UPI tahun pelajaran 2015/2016 memberikan kontribusi yang berarti secara positif terhadap kelulusan siswa yang bersangkutan". Dengan demikian, hipotesis yang diajukan dalam penelitian ini terbukti.

\section{KESIMPULAN}

Siswa kelas IX SMP (Sekolah Menengah Pertama) Laboratorium UPI (Universitas Pendidikan Indonesia) di Bandung tahun pelajaran 2015/2016, secara keseluruhan, dinyatakan lulus dalam proses pembelajaran di tingkat satuan pendidikan SMP dengan kategori "sangat baik". 
Sementara ditinjau dari distribusi kelulusan individu siswanya, sebagian besar siswa (64.18\%) dinyatakan lulus dengan kategori "sangat baik", dan sisanya dinyatakan lulus dengan kategori "baik".

Pencapaian nilai hasil UN (Ujian Nasional) yang diperoleh siswa kelas IX SMP Laboratorium UPI tahun pelajaran 2015/2016, secara keseluruhan, menunjukan kategori "cukup" dengan rata-rata perolehan nilai tiap mata pelajaran sebesar 67.19.

Rata-rata nilai tertinggi yang dicapai siswa adalah pada mata pelajaran Bahasa Indonesia, dan rata-rata nilai terendah pada mata pelajaran Matematika. Ditinjau dari jumlah siswa yang memperoleh nilai ujian nasional, lebih dari setengahnya tergolong pada kategori "cukup" dan "kurang", yakni $33.58 \%$ dan 20.89\%; sedangkan selebihnya tergolong pada kategori "baik" dan "sangat baik", yakni $36.57 \%$ dan $8.96 \%$.

Pencapaian nilai hasil UN yang diperoleh siswa kelas IX SMP Laboratorium UPI tahun pelajaran 2015/2016, secara keseluruhan, memberikan kontribusi positif secara signifikan terhadap tingkat kelulusan siswa yang bersangkutan, dengan kotribusi sebesar $69.7 \%$, sedangkan sisanya sebesar $30.3 \%$ ditentukan oleh faktor lain.

Berdasarkan nasil penelitian dan kesimpulan yang telah dilakukan, maka beberapa saran dapat dikemukakan, sebagai berikut:

Bagi pihak sekolah, khususnya SMP Laboratorium UPI, perlu mengkaji secara mendalam hasil pencapaian nilai ujian nasional siswanya sebagai bahan pertimbangan dalam peningkatan dan pengembangan mutu layanan pendidikan, khususnya layanan pembelajaran siswa, dimana hasil ujian nasional ini dapat mencerminkan optimal-tidaknya proses pembelajaran yang diterapkan di sekolah pada mata pelajaran yang dijadikan mata ujian nasional. Sehingga hal tersebut dapat dijadikan rujukan bagi peningkatan proses pembelajaran pada mata pelajaran lain.
Bagi pihak pemerintah, khususnya yang membidangi pendidikan dasar dan menengah, perlu terus mengembangkan sistem ujian nasional sebagai ujian terstandar, sekaligus sebagai instrumen pengukuran kualitas sistem pendidikan, sehingga ujian nasional ini menjadi instrumen yang valid, reliabel, dan bernilai, baik dalam hal konten, konteks, kompetensi, maupun tantangan kreativitas dalam dunia pendidikan nasional. ${ }^{2}$

\section{Referensi}

Arikunto, S. (2010). Prosedur Penelitian: Suatu Pendekatan Praktik. Jakarta: PT Rineka Cipta.

Athanasou, J. \& I. Lamprianou. (2002). A Teacher's Guide to Assesmen. Tuggerrah-New South Wales: Social Science Press.

Bachman, L.F. (1990). Fundamental Considerations in Language Testing. New York: Longman.

Binkley, M. et al. (2010). Assesment and Teaching of 21st Century Skill. Melbourne: The University of Melbourne Press.

BSNP [Badan Standar Nasional Pendidikan]. (2015). Peraturan Badan Standar Nasional Pendidikan Nomor: 0034/P/BSNP/XII/2015 tentang Prosedur Operasional Standar Penyelenggaraan Ujian Nasional Tahun Pelajaran 2015/2016. Jakarta: Badan Standar Nasional Pendidikan.

Charles, R., F. Lester \& P.O. Daffer. (1991). How to Evaluate Progress in Problem Solving. Reston, VA: National Council of Teachers of Mathematics.

"Data Kelulusan Siswa SMP Lab UPI Tahun 2016". Data Penelitian milik Penulis dan tidak diterbitkan.

"Data Nilai UN Siswa SMP Lab UPI Tahun 2016". Data Penelitian milik Penulis dan tidak diterbitkan.

Forster, M. \& G. Masters. (1996). Performance Assessment: Resource Kit. Camberwell,

${ }^{2}$ Pernyataan: Saya, dengan ini, menyatakan bahwa artikel ini beserta seluruh isinya adalah benar-benar karya saya sendiri melalui hasil penelitian. Saya tidak melakukan penjiplakan atau pengutipan dengan cara-cara yang tidak dibenarkan dalam etika keilmuan yang berlaku dalam dunia akademis. Saya bersedia menanggung hukuman secara akademik, sekiranya pernyataan yang saya buat ini tidak sesuai dengan kenyataan. Demikian surat pernyataan ini dibuat untuk dipergunakan sebagaimana mestinya. 
Melborne: The Australian Council for Educational Research, Ltd.

Hidayah, N. (2013). "Ujian Nasional dalam Perspektif Kebijakan Publik" dalam Jurnal Pencerahan Majelis Pendidikan Daerah Aceh, Vol.7(1), Maret, hlm.35-40.

Jumiati, M. Sari \& D. Akmalia. (2011). "Peningkatan Hasil Belajar Siswa dengan Menggunakan Model Numbereds Heads Together (NHT) pada Materi Gerak Tumbuhan di Kelas VIII SMP Sei Putih Kampar" dalam Lectura, Vol.2, No.2 [Agustus]. Tersedia secara online di: https://www.unilak. ac.id/media/file/73452042508Martalasari-jumiatidian.pdf [diakses di Bandung, Indonesia: 12 Oktober 2016].

Kemendikbud RI [Kementerian Pendidikan dan Kebudayaan Republik Indonesia]. (2013). Peraturan Menteri Pendidikan dan Kebudayaan Nomor 54 Tahun 2013 tentang Standar Kompetensi Lulusan (SKL). Jakarta: Kementerian Pendidikan dan Kebudayaan Republik Indonesia.

Kemdikbud RI [Kementerian Pendidikan dan Kebudayaan Republik Indonesia]. (2015a). "Kebijakan Perubahan Ujian Nasional". Laporan Presentasi tentang Perubahan UN (Ujian Nasional), pada tanggal 23 Januari 2015 di Jakarta. Kemendikbud RI [Kementerian Pendidikan dan Kebudayaan Republik Indonesia]. (2015b). Peraturan Menteri Pendidikan dan Kebudayaan Nomor 5 Tahun 2015 tentang Kriteria Kelulusan Peserta Didik, Penyelenggaraan Ujian Nasional, dan Penyelenggaraan Ujian Sekolah/Madrasah/ Pendidikan Kesetaraan pada SMP/MTs atau yang Sederajat dan SMA/MA/SMK atau yang Sederajat. Jakarta: Kementerian Pendidikan dan Kebudayaan Republik Indonesia.

Kemendikbud RI [Kementerian Pendidikan dan Kebudayaan Republik Indonesia]. (2015c). Peraturan Menteri Pendidikan dan Kebudayaan Nomor 57 Tahun 2015 tentang Penilaian Hasil Belajar oleh Pemerintah melalui Ujian Nasional dan Penilaian Hasil Belajar oleh Satuan Pendidikan melalui Ujian Sekolah/Madrasah/ Pendidikan Kesetaraan pada SMP/MTs atau yang Sederajat dan SMA/MA/SMK atau yang Sederajat. Jakarta: Kementerian Pendidikan dan Kebudayaan Republik Indonesia.

Maryani, E. \& H. Sjamsuddin. (2009). "Pengembangan Program Pembelajaran IPS untuk Meningkatkan Kompetensi Keterampilan Sosial" dalam Jurnal Penelitian, Vol.9, No.1 [April]. Tersedia secara online di: http://file.upi.edu/

\section{Direktori/JURNAL/JURNAL PENELITIAN}

PENDIDIKAN [diakses di Bandung, Indonesia: 12 Oktober 2016].

Maulipaksi, D. (2016). "UN Bukan Penentu Kelulusan: Ini Pertimbangan Kelulusan Siswa". Tersedia secara online di: http://www.kemdikbud. go.id/main/blog/2016/05/un-bukan-penentukelulusan-ini-pertimbangan-kelulusan-siswa [diakses di Bandung, Indonesia: 12 Oktober 2016].

Mueller, D.J. (1992). Mengukur Sikap Sosial: Pegangan untuk Peneliti dan Praktisi. Jakarta: Bumi Aksara.

Muhadjir, Noeng. (1993). Ilmu Pendidikan dan Perubahan Sosial: Suatu Teori Pendidikan. Yogyakarta: Tiara Wacana bekerjasama dengan IKIP Muhammadiyah.

Nitko, J.A. (1996). Educational Assesmen of Students. Englewood Cliffs, New York: Merril, an Imprint of Prentice Hall.

Phillips, M. et al. (1998). "Family Background, Parenting Practices, and the Black-White Test Score Gap" in C. Jencks \& M. Phillips [eds]. The Black-White Test Score Gap. Washington, DC: Brookings Institution Press, pp.103-145.

Putra, Riza Anugrah, Mustofa Kamil \& Joni Rahmat Pramudia. (2017). "Penerapan Metode Pembelajaran Mandiri dalam Meningkatkan Hasil Belajar Peserta Didik: Studi pada Program Pendidikan Kesetaraan Paket C di PKBM Bina Mandiri Cipageran" dalam Jurnal Pendidikan Luar Sekolah, Vol.I, No.1 [April]. Tersedia secara online juga di: file:///C:/Users/acer/ Downloads/6940-13864-1-SM\%20(1).pdf [diakses di Bandung, Indonesia: 1 Juni 2017].

Setneg RI [Sekretariat Negara Republik Indonesia]. (2000). Undang-Undang Dasar Negara Republik Indonesia Tahun 1945. Jakarta: Sekretariat Negara Republik Indonesia.

Setneg RI [Sekretariat Negara Republik Indonesia]. (2003). Undang-Undang Nomor 20 Tahun 2003 tentang Sistem Pendidikan Nasional. Jakarta: Sekretariat Negara Republik Indonesia.

Sugiyono. (2012). Metode Penelitian: Kuantitatif, Kualitatif, dan R\&D. Bandung: Penerbit Alfabeta.

Sulistyo, G. (2007). “Ujian Nasional (UN): Harapan, Tantangan, dan Peluang” dalam Wacana, Vol.9(1), April, hlm.79-106.

"Ujian” dalam KBBI (Kamus Besar Bahasa Indonesia). Jakarta: Kementerian Pendidikan dan Kebudayaan Republik Indonesia, 2016. Tersedia secara online juga di: http://www.kbbi.web.id [diakses di Bandung, Indonesia: 12 Oktober 2016]. 


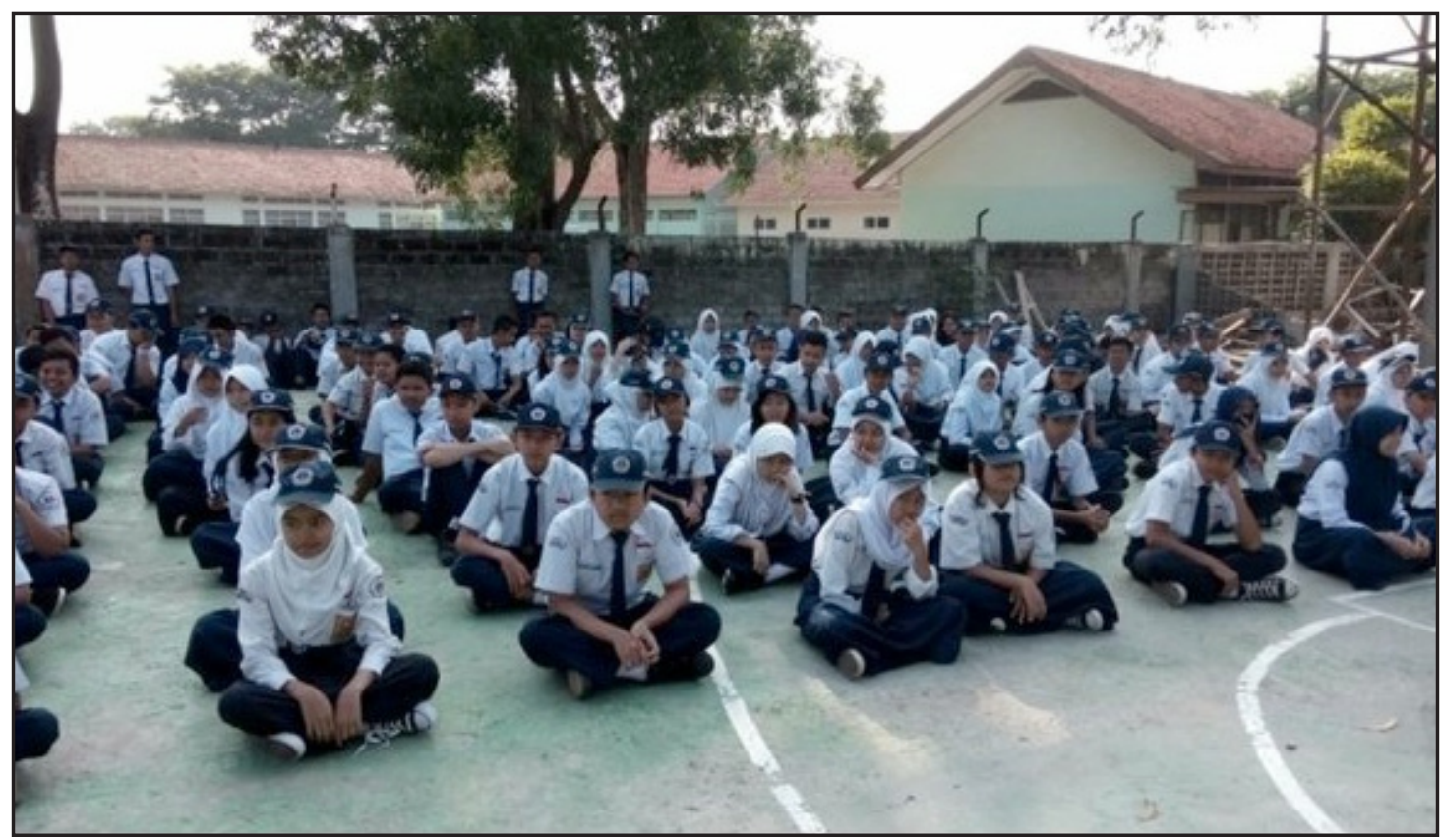

Siswa SMP Laboratorium UPI di Bandung

(Sumber: http://bayupratamahidayah.blogspot.co.id, 20/5/2017)

Siswa kelas IX SMP (Sekolah Menengah Pertama) Laboratorium UPI (Universitas Pendidikan Indonesia) di Bandung tahun pelajaran 2015/2016, secara keseluruhan, dinyatakan lulus dalam proses pembelajaran di tingkat satuan pendidikan SMP dengan kategori "sangat baik". Sementara ditinjau dari distribusi kelulusan individu siswanya, sebagian besar siswa (64.18\%) dinyatakan lulus dengan kategori "sangat baik", dan sisanya dinyatakan lulus dengan kategori "baik". 